\title{
Study of Commercially Available Paddy Transplanters in Telangana State
}

\author{
P. Rajaiah, B. Laxman, A. Pramod Reddy, B. Vennela Reddy and P. Sudhakar Reddy* \\ PJSTSAU, Telangana, Hyderabad-30, India \\ *Corresponding author
}

K e y w o r d s
Paddy transplanters,
Number of
seedlings/hill,
Missing hills, Mat
nursery, Field
efficiency

\section{Introduction}

Rice is the world's most important crop and a staple food for more than half of the world's population. Rice ranks third after wheat and maize in terms of worldwide production. About $90 \%$ of the world's rice (160 million ha of area with a production of 759 million tons of paddy) is grown and produced in Asia
Rice is the staple food of Telangana State requires about 50 lakh tons annually to feed the population. Rice is being cultivated both in kharif and rabi season as one of the most important crop in Telangana. During the year, 2017-18 rice crop was grown in an area of about 17.2 lakh hectares and produced 58.3 lakh tons of rice with the productivity of 3387 $\mathrm{kg} / \mathrm{ha}$. Comparing the productivity of rice over other states, Telangana was in first place by crossing the leading states like Punjab, Haryana, Tamilnadu and Andhra Pradesh. Manual transplanting involves lot of drudgery and requires 250-300 man hours/ha. Further, due to rapid industrialization and migration of labor to urban areas, manual transplanting was found costly leading to reduced profits to farmers. Self propelled paddy transplanters have been using in the state for some time by using mat type nursery raised in plastic trays or in the field itself. In this study six numbers of four row, four numbers of six row and two numbers of eight rows of seven manufacturing companies were evaluated in the sandy clay loam soil to see the feasibility of transplanters to be supplied to the progressive farmers in the state by the Govt. of Telangana. Nursery was raised in the field by spreading 60 micron polythene sheet over the wet soil and sprinkled the paddy grain on the soil. The average forward speed of transplanters was observed at $2.5 \mathrm{~km} / \mathrm{h}$. The number of seedlings/hill was observed as 3-8. The plant to plant spacing and row to row spacing range was observed as 12.0 to $17.5 \mathrm{~cm}$ and 23.8 to $30 \mathrm{~cm}$ respectively. The average field capacity, fuel consumption and field efficiency of riding type transplanters varied from 0.2 to $0.46 \mathrm{ha} / \mathrm{h}$, 1.3 to $2.3 \mathrm{lit} / \mathrm{h}$ and 74.88 to 81.33 per cent respectively and the field capacity, field efficiency, fuel consumption of different walk behind type transplanters ranged from 0.33 to $0.38 \mathrm{ha} / \mathrm{h}, 75.12$ to $81.27 \%$ and 1.4 to $1.7 \mathrm{l} / \mathrm{h}$ respectively. 
But the main concern with drum seeders was less capacity and suitable only for small scale farming community. Moreover, this method requires considerably higher seed rate and often exposes the seed to damage by birds and environment. Of late, the availability of manual labour for transplanting rice has decreased drastically due to migration of labour from villages to cities for more wages which has led to manual transplanting difficult. Mechanical transplanters developed in Japan, China, Korea and India have been using in the recent past for paddy transplanting by using mat nursery to overcome the labour problems. This paper illustrates the performance of commercially available paddy transplanters among the farming community.

The study was undertaken at Agricultural Research Institute, PJTSAU, Rajendranagar, Hyderabad, Telangana State during kharif season of 2018. The experiment conducted to evaluate the field performance of riding and walking type paddy transplanters of different companies. In this study, five number of walk behind and six number of riding type transplanters (Fig. 1 and 2) were evaluated in the sandy clay loam soil. The specifications of the paddy transplanters selected for the study are furnished (Table 1 and 2).

\section{Nursery preparation}

The nursery was raised in two methods trays i.e., mat type or tray type nursery in the Agricultural Research Institute field. For mechanical transplanting, like conventional method, nursery is not raised in plots or fields. The machine can transplant soil bearing seedlings prepared in mat type nursery. For preparation of mat type nursery, a special nursery bed is prepared on a flat piece of land using polythene sheets. Wooden/Iron frames having $50 \times 22 \times 2.5 \mathrm{~cm}$ sized compartments are placed on the polythene sheet. First, the pebbles free fine farm yard manure is mixed with it. The soil is filled uniformly in all compartments and gently compacted up to a thickness of $2 \mathrm{~cm}$. The seed rate is decided according to size variety, medium size variety and large size variety is $8-10 \mathrm{~kg} / \mathrm{acre}, 10-12 \mathrm{~kg} / \mathrm{acre}$ and 12 $15 \mathrm{~kg} /$ acre respectively. The selected seed is soaked in water for $24 \mathrm{~h}$. Thereafter the water is removed and allowed to incubation for another $24 \mathrm{~h}$ in gunny bags in order to get sprouting and the sprouted seeds are evenly broadcasted on the mats. Then the seed is covered with very thin layer of fine soil.

Seedlings will be ready for transplanting by 16 to 18 days after sowing, when the height of the plant reaches $10-15 \mathrm{~cm}$ with 3-4 leaves can be used for the transplanting and the number of plants per hill depend upon the amount of seed placed in the tray to form mat during raising of nursery. If the amount of seed placed more, the number of hills per plant increases during transplanting.

\section{Results and Discussion}

Based on the field experiments, it was observed that the number of seedlings/hill for riding type transplanters ranged from 3-8 seedlings per hill where as in case of walk behind transplanters it was observed in the range of 3-7 seedlings per hill, the number of seedlings/hill will vary depending up on the skill in raising nursery.

The plant to plant spacing for different companies riding type transplanters ranged from 12-17.5 cm whereas, in case of walk behind transplanters the plant to plant spacing was observed in the range of 12-16 $\mathrm{cm}$ and the row to row spacing for riding type and walk behind transplanters maintained at a constant spacing of $30 \mathrm{~cm}$ except VST and Redlands companies where the row spacing was $23.8 \mathrm{~cm}$ (Table 3 ). 
Field results revealed that the field capacity of different riding type transplanters ranged from 0.2 to $0.46 \mathrm{ha} / \mathrm{hr}$, the field efficiency and fuel consumption for different riding type transplanters ranged from 74.88 to $81.33 \%$ and 1.3 to $2.4 \mathrm{l} / \mathrm{h}$ respectively (Table 4 ).
Further, field results revealed that the field capacity of different walk behind type transplanters ranged from 0.33 to $0.38 \mathrm{ha} / \mathrm{h}$, the field efficiency and fuel consumption for different walk behind type transplanters ranged from 75.12 to $81.27 \%$ and 1.4 to 1.7 $1 / \mathrm{h}$ respectively (Table 5).

Table.1 Specifications of different companies walk behind transplanters

\begin{tabular}{|c|c|c|c|c|c|}
\hline \multirow{2}{*}{$\begin{array}{l}\text { Name of the } \\
\text { company }\end{array}$} & \multicolumn{5}{|c|}{ Specifications } \\
\hline & Model & $\begin{array}{l}\text { Approx. } \\
\text { Cost of } \\
\text { Machine } \\
\text { (Rs lakhs) }\end{array}$ & Type & $\begin{array}{l}\text { Fuel } \\
\text { type }\end{array}$ & $\begin{array}{c}\text { Engine } \\
\text { (HP) }\end{array}$ \\
\hline $\begin{array}{c}\text { YANMAR } \\
\text { (JAPAN) }\end{array}$ & AP 4 & 2.48 & $\begin{array}{l}\text { Walk } \\
\text { Behind }\end{array}$ & Petrol & 3.5 \\
\hline KUBOTO (JAPAN) & NSP4W & 2.49 & $\begin{array}{c}\text { Walk } \\
\text { Behind }\end{array}$ & Petrol & 4.3 \\
\hline KUKJE (KOREA) & 2ZS4A & 2.45 & $\begin{array}{c}\text { Walk } \\
\text { Behind }\end{array}$ & Petrol & 4.5 \\
\hline $\begin{array}{c}\text { CLASS } \\
\text { (INDIA) }\end{array}$ & $\begin{array}{c}\text { PADDY } \\
\text { PANTHER } \\
14\end{array}$ & 3.03 & $\begin{array}{l}\text { Walk } \\
\text { Behind }\end{array}$ & Petrol & 3 \\
\hline $\begin{array}{l}\text { MAHINDRA and } \\
\text { MAHINDRA } \\
\text { (INDIA) }\end{array}$ & MP461 & 2.25 & $\begin{array}{l}\text { Walk } \\
\text { Behind }\end{array}$ & Petrol & 5 \\
\hline
\end{tabular}

Table.2 Specifications of different companies riding type transplanters

\begin{tabular}{|c|c|c|c|c|c|}
\hline \multirow{2}{*}{$\begin{array}{c}\text { Name of the } \\
\text { company }\end{array}$} & Model & $\begin{array}{c}\text { Specifications } \\
\text { Approx. Cost } \\
\text { of Machine } \\
\text { (Rs lakhs) }\end{array}$ & Type & Fuel type & $\begin{array}{c}\text { Engine } \\
\text { (HP) }\end{array}$ \\
\cline { 2 - 6 } & & 14 & Riding & Diesel & 21 \\
\hline YANMAR & VP6D & 13.26 & Riding & Diesel & 21 \\
\hline KUBOTO & SPV6MD & 12.57 & Riding & Petrol & 22 \\
\hline CLASS & $\begin{array}{c}\text { PADDY } \\
\text { PANTHER 26 }\end{array}$ & 13.4 & Riding & Diesel & 18 \\
\hline KUKJE & RGO60SD & 13.5 & Riding & Diesel & 4 \\
\hline VST & YANJI SHAKTI & 2.5 & Riding & Diesel & 5 \\
\hline REDLANDS & RP824 & 2.25 & & & \\
\hline
\end{tabular}


Table.3 Field observation of different types of transplanters

\begin{tabular}{|c|c|c|c|c|c|}
\hline \multirow{2}{*}{$\begin{array}{l}\text { Name of the } \\
\text { company }\end{array}$} & \multirow[t]{2}{*}{ Model } & \multirow[t]{2}{*}{ Type } & \multicolumn{3}{|c|}{ Observations } \\
\hline & & & $\begin{array}{c}\text { No. of } \\
\text { seedlings/hill }\end{array}$ & $\begin{array}{c}\text { Plant to } \\
\text { Plant } \\
\text { Spacing }(\mathrm{cm})\end{array}$ & $\begin{array}{l}\text { Row to Row } \\
\text { spacing }(\mathrm{cm})\end{array}$ \\
\hline \multirow{2}{*}{$\begin{array}{l}\text { YANMAR } \\
\text { (JAPAN) }\end{array}$} & VP6D & Riding & $4-6$ & 13 & 30 \\
\hline & AP 4 & Walk Behind & $3-5$ & 12.5 & 30 \\
\hline \multirow{2}{*}{$\begin{array}{c}\text { KUBOTO } \\
\text { (JAPAN) }\end{array}$} & SPV6MD & Riding & $3-5$ & 12 & 30 \\
\hline & NSP4W & Walk Behind & $3-6$ & 12 & 30 \\
\hline \multirow{2}{*}{$\begin{array}{c}\text { KUKJE } \\
\text { (KOREA) }\end{array}$} & RGO60SD & Riding & $4-7$ & 13 & 30 \\
\hline & 2ZS4A & Walk Behind & $6-7$ & 12.5 & 30 \\
\hline \multirow[t]{2}{*}{$\begin{array}{c}\text { CLASS } \\
\text { (INDIA) }\end{array}$} & $\begin{array}{c}\text { PADDY } \\
\text { PANTHER } 26\end{array}$ & Riding & $6-8$ & 14 & 30 \\
\hline & $\begin{array}{c}\text { PADDY } \\
\text { PANTHER } 14\end{array}$ & Walk Behind & $5-7$ & 12.5 & 30 \\
\hline $\begin{array}{c}\text { VST } \\
\text { (CHINA) }\end{array}$ & YANJI SHAKTI & Riding & $7-8$ & 16 & 23.8 \\
\hline $\begin{array}{l}\text { MAHINDRA } \\
\text { and } \\
\text { MAHINDRA } \\
\text { (INDIA) }\end{array}$ & MP461 & Walk Behind & $6-7$ & 15 & 30 \\
\hline $\begin{array}{l}\text { REDLANDS } \\
\text { (INDIA) }\end{array}$ & RP824 & Riding & $5-7$ & 17.5 & 23.8 \\
\hline
\end{tabular}

Table.4 Field performance of different riding types of transplanters

\begin{tabular}{|c|c|c|c|}
\hline \multirow{2}{*}{$\begin{array}{c}\text { Name of the } \\
\text { company }\end{array}$} & \multicolumn{3}{|c|}{ Observations } \\
\cline { 2 - 4 } & $\begin{array}{c}\text { Field capacity } \\
\text { (ha/h) }\end{array}$ & $\begin{array}{c}\text { Field efficiency } \\
(\mathbf{\%})\end{array}$ & $\begin{array}{c}\text { Fuel consumption } \\
(\mathbf{l} / \mathbf{h})\end{array}$ \\
\hline YANMAR & 0.46 & 81.33 & 2.3 \\
\hline KUBOTO & 0.42 & 80.24 & 2.2 \\
\hline CLASS & 0.40 & 80.8 & 2.4 \\
\hline KUKJE & 0.39 & 79.88 & 2.4 \\
\hline VST & 0.20 & 75.66 & 1.3 \\
\hline REDLANDS & 0.21 & 74.88 & 1.5 \\
\hline
\end{tabular}


Table.5 Field performance of different walk behind types of transplanters

\begin{tabular}{|c|c|c|c|}
\hline \multirow{2}{*}{ Name of the company } & \multicolumn{3}{|c|}{ Observations } \\
\cline { 2 - 4 } & $\begin{array}{c}\text { Field capacity } \\
\text { (ha/h) }\end{array}$ & $\begin{array}{c}\text { Field efficiency } \\
(\mathbf{\%})\end{array}$ & $\begin{array}{c}\text { Fuel consumption } \\
(\mathbf{l} / \mathbf{h})\end{array}$ \\
\hline YANMAR & 0.34 & 75.78 & 1.7 \\
\hline KUBOTO & 0.38 & 81.27 & 1.5 \\
\hline CLASS & 0.35 & 76.24 & 1.4 \\
\hline KUKJE & 0.33 & 75.12 & 1.6 \\
\hline MAHINDRA and MAHINDRA & 0.37 & 80.89 & 1.5 \\
\hline (INDIA) & & & \\
\hline
\end{tabular}

Fig.1 Different types of riding type paddy transplanters used for field evaluation
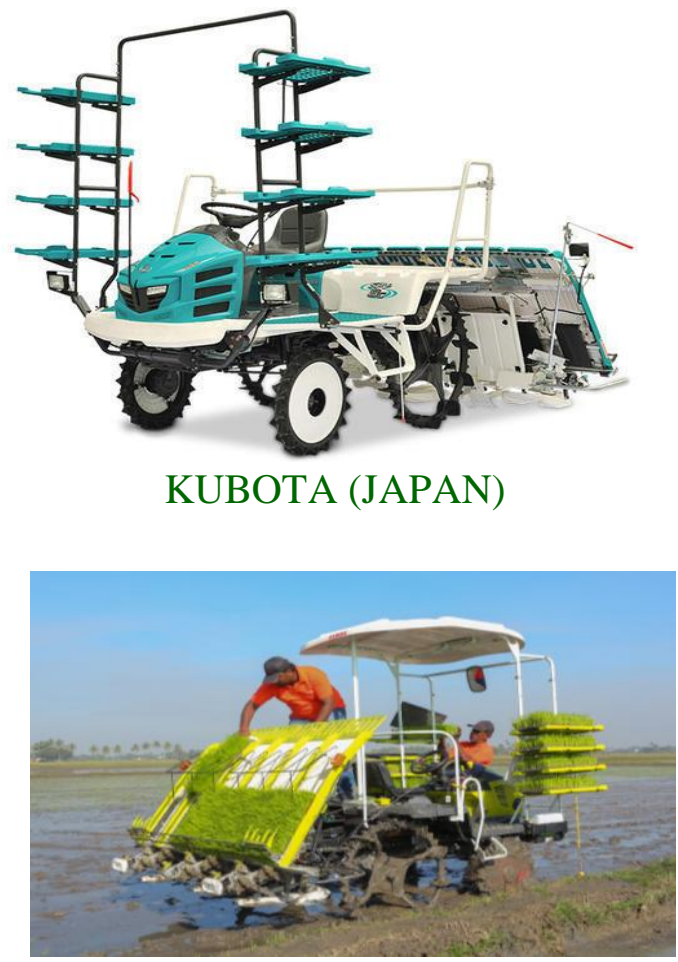

CLASS (INDIA)

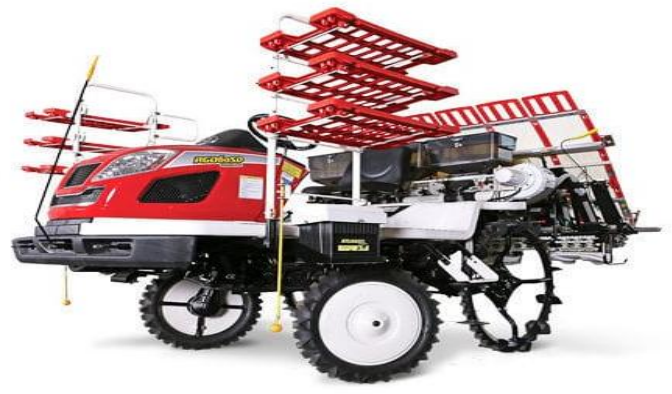

KUKJE (KOREA)
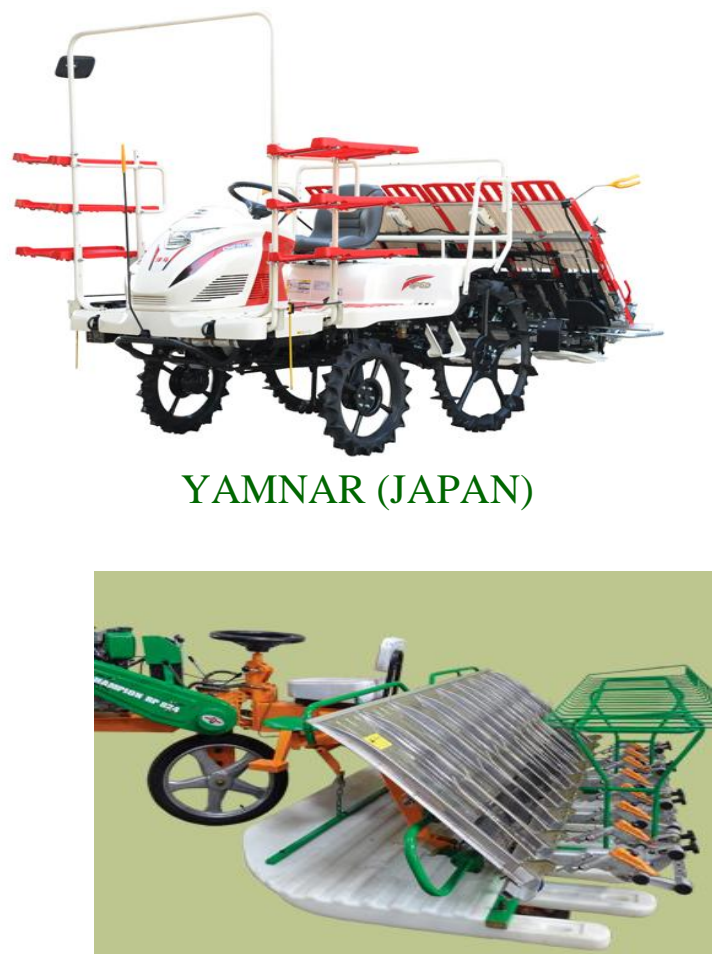

REDLANDS (INDIA)

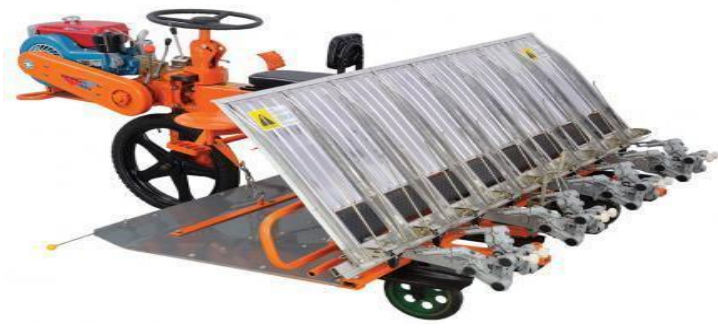

VST TILLERS (CHINA) 
Fig.2 Different types of walk behind type paddy transplanters used for field evaluation

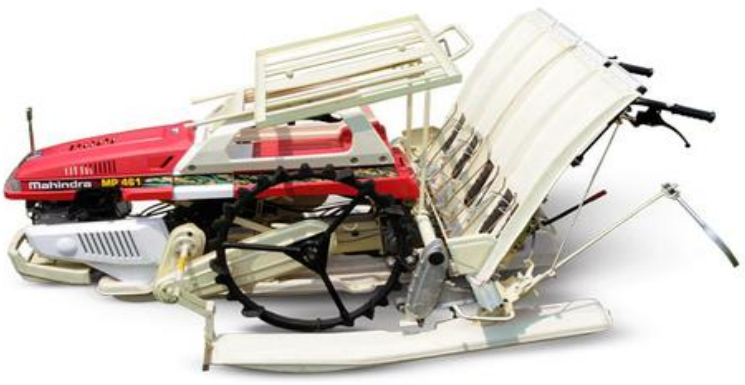

MAHINDRA\&MAHINDRA (INDIA)

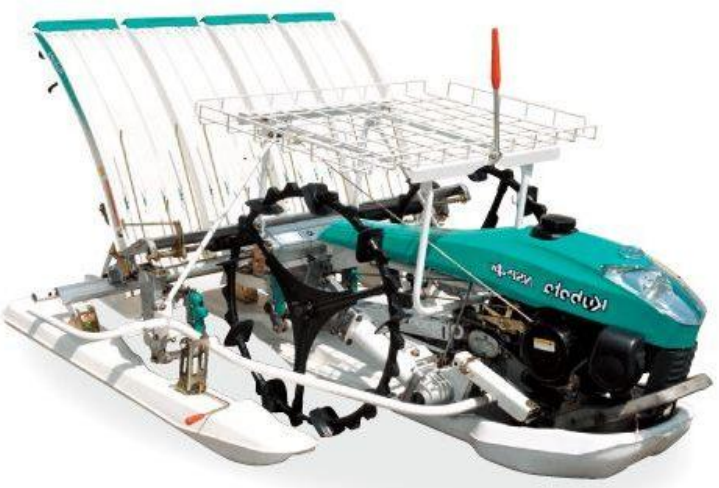

KUBOTO (JAPAN)

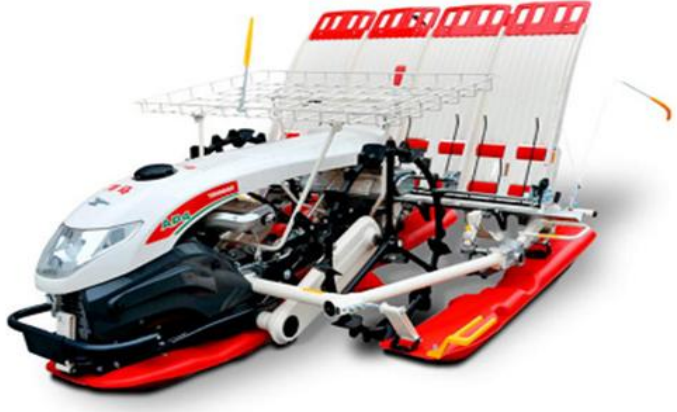

YANMAR (JAPAN)

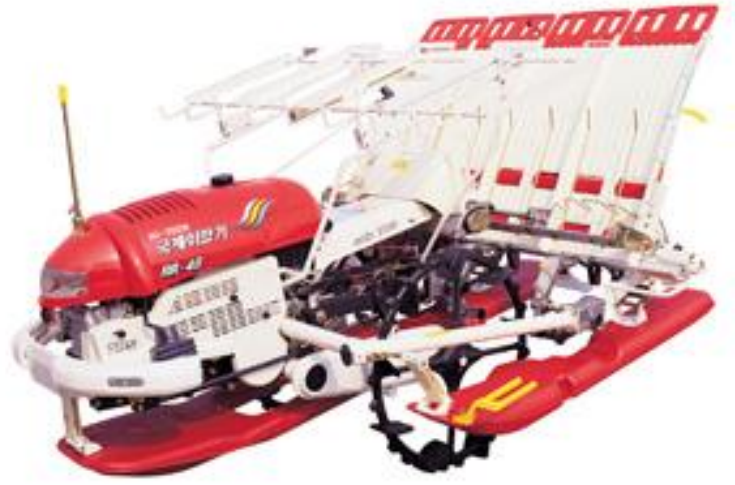

KUKJE (KOREA)

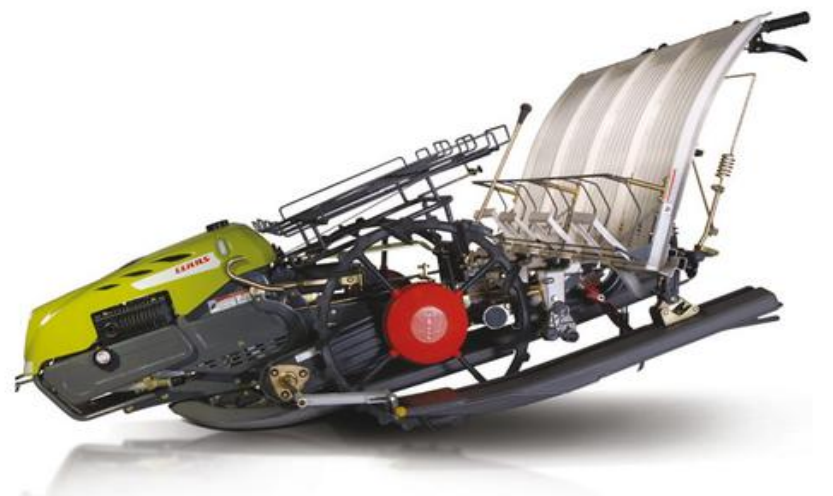

In conclusions, the performance of the paddy transplanters was on par with conventional transplanting in terms of plant spacing and no of seedlings per hill but saved labour and time. The adoption of paddy transplanters in
Telangana region can be boosted up by supplying them through government subsidy which will increase the mechanization in paddy and to overcome the labour problem. 


\section{References}

Anonymous. 2010. Philippine Agricultural Engineering Standard Agricultural Machinery - Mechanical Rice Transplanter-Methods of Test. PAES 152 www.bps.dti.gov.ph

Anonymous. 2015. Final estimates of area, production and productivity of principal crops during 2013-14 in M.S. http://www.mahaagri.gov.in

Pateriya, R. N. and R. K. Datta (2012). Design modifications of mat type rice transplanter. International Journal of Advanced Technology and Engineering Research (IJATER) Vol.2 (6): 87.
Patil S. B., Shahare P. U and V. V. Aware. 2016. Study of different commercially available paddy transplanters in Konkan region of Maharashtra state. International Journal of Agricultural Science and Research (IJASR). Vol. 6(6): 247-252

Shahare P.U. 2012. Agricultural mechanization in Konkan region of Maharashtra Agricultural Engineering Today Vol. 36(2):6-9

Shahare P.U. and M.R. Bhat. 2011. Development and performance evaluation of two row paddy transplanter. International Journal of Agricultural. Engineering, 4 (1): 103 105.

\section{How to cite this article:}

Rajaiah, P., B. Laxman, A. Pramod Reddy, B. Vennela Reddy and Sudhakar Reddy, P. 2019. Study of Commercially Available Paddy Transplanters in Telangana State. Int.J.Curr.Microbiol.App.Sci. 8(03): 1066-1072. doi: https://doi.org/10.20546/ijcmas.2019.803.129 